\section{Sensory and Nutritional Characteristics of Concept Frozen Desserts Made from Underutilized Sweetpotato Roots}

\author{
Shinyoung Kim ${ }^{1}$, Stephen L. Meyers ${ }^{2}$, Juan L. Silva ${ }^{1}$, \\ M. Wesley Schilling ${ }^{1}$, and Lurdes Siberio Wood ${ }^{1}$
}

ADDITIONAL INDEX WORDs. almond milk, ice cream, Ipomoea batatas, soy milk

SUMMARY. A traditional dairy-based frozen dessert (ice cream) was developed with three levels of sweetpotato (Ipomoea batatas) puree [ $20 \%, 30 \%$, and $40 \%$ (by weight)] to determine the impact of sweetpotato content on product functionality, nutritional content, and sensory characteristics. Increased sweetpotato puree resulted in increased orange color, flavor intensity, and sweetpotato flavor, but $40 \%$ puree proved difficult to incorporate into the mixture. Additionally, nondairy frozen desserts containing $30 \%$ sweetpotato puree were compared with a milk-based control in which all ingredients were the same except that milk was replaced with soy (Glycine max) and almond (Prunus dulcis) milk. Consumer acceptability tests were conducted with panelists at Mississippi State University $(n=101)$ and in Pontotoc, MS $(n=43)$. Panelists in Pontotoc rated the overall acceptability of all three frozen desserts the same, but they preferred the appearance of the milk-based frozen dessert over that of soy- and almond-based milk alternatives. According to the panelists at Mississippi State, the milk-based frozen dessert had greater overall acceptability and aroma than the almond-based dessert and a preferential texture and appearance compared with the soy- and almond-based desserts. Milk-, soy-, and almond-based frozen desserts were rated as "slightly liked" or better by $92 \%, 80 \%$, and $69 \%$ of the panelists, respectively.

S weetpotato (Ipomoea batatas) is the seventh most consumed staple food in the world and is considered a food security staple in developing countries due to its adaptability to climate change and productivity under drought conditions (Bonvell-Benjamin, 2007). The main component of sweetpotato is complex starch, yielding one of the densest caloric root vegetables, $86 \mathrm{kcal} /$ 100 g [U.S. Department of Agriculture (USDA), 2018]. Sweetpotato has a lower glycemic index (GI) than simple carbohydrate sources, and the

$\overline{\text { Received for publication } 1 \text { Sept. 2020. Accepted for }}$ publication 20 Jan. 2021.

Published online 15 April 2021.

${ }^{1}$ Department of Food Science, Nutrition, and Health Promotion, Mississippi State University, Mississippi State, MS 39762

${ }^{2}$ North Mississippi Research and Extension Center, Pontotoc Ridge-Flatwoods Branch Experiment Station, Mississippi State University, Pontotoc, MS 38863

Current address for S.L.M.: Department of Horticulture and Landscape Architecture, Purdue University, West Lafayette, IN 47907.

J.L.S. is the corresponding author. E-mail: jsilva@ foodscience.msstate.edu.

This is an open access article distributed under the CC BY-NC-ND license (https://creativecommons.org/ licenses/by-nc-nd/4.0/).

https://doi.org/10.21273/HORTTECH04725-20 abundance of fiber prevents the absorption of glucose in the small intestine, thereby reducing the rate of insulin secretion (Jenkins et al., 1988). For this reason, sweetpotato is considered a good substitute in diabetic and weight control diets for simple, starchy foods such as white bread and potatoes (Solanum tuberosum) (Jenkins et al., 1988). The crop also has a variety of nutritional benefits with respect to both macro- and micronutrients, is abundant in antioxidants, and orange-fleshed cultivars are prominent in carotenoids (Burri, 2011). United States sweetpotato production has greatly increased during the past 15 years, reaching 3.1 billion pounds in 2015 [USDANational Agriculture Statistics Service
(NASS), 2018]. Per capita consumption of sweetpotato increased from 4.2 to 7.6 $\mathrm{lb}$ from 2000 to 2015 due in part to awareness of its nutritive value and its increased use in value-added food products.

Mississippi is the third largest producer of sweetpotatoes after North Carolina and California (USDA-NASS, 2018). Sweetpotato is the fourth most valuable crop in Mississippi after soybeans (Glycine max), cotton (Gossypium hirsutum), and corn (Zea mays) (USDA-NASS, 2018). Between 2000 and 2015, Mississippi sweetpotato production increased by $155 \%$ (Johnson et al., 2015). In 2017, 29,000 acres were harvested (USDANASS, 2018). During an evaluation of the 2011 season, Morgan et al. (2012) reported that the Mississippi sweetpotato industry employed 1059 fulltime equivalents. With the steady growth in recent years, the direct output has doubled from $\$ 66.4$ million to $\$ 123$ million in 2017 (USDA-NASS, 2018), with nearly an equivalent indirect impact (Morgan et al., 2012).

In addition to the increased production and consumption of sweetpotatoes, there is also increasing scrutiny of produce buyers and consumers of aesthetically pleasing sweetpotatoes meeting stringent guidelines for qualities, including size and shape. For example, Collart et al. (2019) reported that consumer willingnessto-pay for sweetpotatoes decreased as the portion of the sweetpotato skin affected by skinning injury increased. For the 2018 crop year, Meyers (2019) reported that many Mississippi producers did not harvest processing grade sweetpotatoes because of their low value and lack of valueadded outlets. As a result, there is a need to develop additional valueadded uses for processing grade sweetpotatoes that do not meet

\begin{tabular}{llll}
\hline $\begin{array}{l}\text { Units } \\
\begin{array}{l}\text { To convert U.S. to SI, } \\
\text { multiply by }\end{array}\end{array}$ & U.S. unit & SI unit & $\begin{array}{l}\text { To convert SI to U.S., } \\
\text { multiply by }\end{array}$ \\
\hline 29.5735 & $\mathrm{fl} \mathrm{oz}$ & $\mathrm{mL}$ & 0.0338 \\
2.54 & inch(es) & $\mathrm{cm}$ & 0.3937 \\
25.4 & inch(es) & $\mathrm{mm}$ & 0.0394 \\
4.1868 & kilocalorie $(\mathrm{s})$ & $\mathrm{kJ}$ & 0.2388 \\
0.4536 & $\mathrm{lb}$ & $\mathrm{kg}$ & 2.2046 \\
1 & micron $(\mathrm{s})$ & $\mu \mathrm{m}$ & 1 \\
28.3495 & $\mathrm{oz}$ & $\mathrm{g}$ & 0.0353 \\
28,350 & $\mathrm{Oz}$ & $\mathrm{mg}$ & $3.5274 \times 10^{-5}$ \\
$\left({ }^{\circ} \mathrm{F}-32\right) \div 1.8$ & ${ }^{\circ} \mathrm{F}$ & ${ }^{\circ} \mathrm{C}$ & $\left({ }^{\circ} \mathrm{C} \times 1.8\right)+32$
\end{tabular}


stringent standards required to be sold as a fresh market USDA no. I grade. One sector of value-added foods that has the potential for using processing grade sweetpotatoes is ice creams and nondairy frozen desserts.

Ice cream is a semi-solid foam or custard made from dairy products such as milk, cream, and nonfat milk powder. This complex and sweettasting colloid is frozen below its freezing point so that it is smooth and creamy (Goff, 1997). Commercially produced ice cream incorporates air for a desirable texture and increased volume. Ice cream is a standardized food in the United States that is defined as a dairy frozen dessert when there is a minimum of $10 \%$ fat and less than $50 \%$ overrun (U.S. Food and Drug Administration, 2018). Ice cream is categorized as economy, premium, and super premium based on its fat content, total solids, and overrun. The greater the amount of fat added and the less air incorporated will result in a smoother ice cream. However, dairy-based products, including ice cream, should not be consumed by those requiring a dairy-free diet because of lactose intolerance, dairy allergies, and/or veganism (Mäkinen et al., 2016).

The global nondairy frozen dessert market reached $\$ 400$ million in 2017 (Ahuja and Rawat, 2018). Plant-based milk alternatives used in frozen desserts are typically opaque liquid extracted from legumes or tree nuts, most commonly almond (Prunus dulcis) and soybean. Compared with milk, plant-based milk alternatives are lower in calories and comparable in calcium content (Mäkinen et al., 2016). In nondairy frozen desserts, cream is replaced by vegetable oil to maintain a smooth texture; however, coconut (Cocos nucifera) oil can also be used to improve the texture of frozen desserts by functioning as an emulsifier (Santana et al., 2011). Coconut oil is a highly saturated oil with a sweet aroma. It is a natural source of medium-chain fatty acids (MCFAs), with more than $50 \%$ MCFAs. MCFAs consist of 6 to 10 carbons; therefore, the hydrolysis and absorption of MCFAs is more efficient than that of long-chain fatty acids because the mechanism of its digestion is similar to glucose (Marten et al., 2006). Coconut oil has a high melting point $\left(24.4^{\circ} \mathrm{C}\right)$, which enables the possibility of its use in frozen desserts. Additionally, coconut oil is used in many commercial products to improve health benefits (Choo et al., 2010) and shelf stability.

In nondairy frozen desserts, milk is replaced with fortified plant-based milk alternatives. Whole milk contains $3.3 \%$ protein and almond milk contains $0.5 \%$ protein, which is the lowest concentration of the 14 different milk alternatives on the market. The protein content of soy milk varies according to manufacturers. Almond milk and soy milk contain more fiber and less saturated fat than milk (Mäkinen et al., 2016). Although the market for nondairy frozen desserts is rapidly growing, they are not as acceptable as ice cream. Bisla et al. (2012) reported that ice cream made from $100 \%$ milk was preferred over that made from $100 \%$ soy and other plant-based milk alternative "ice creams." In a sensory evaluation study of milk (whole, reduced fat, and fat-free) and soy milk (vanilla, fortified, and organic), milk was preferred (Palacios et al., 2009). The objective of this study was to develop sweetpotato-based ice creams and nondairy frozen desserts to add value to underused processing grade sweetpotatoes.

\section{Materials and methods Product development}

Product development was conducted at Mississippi State University's Ammerman-Hernsberger Food Processing Laboratory and the Edward W. Custer Dairy Processing Plant, Mississippi State, MS, and it occurred in two phases. During the first phase, a traditional dairy-based frozen dessert (ice cream) was developed with three levels of sweetpotato puree $[20 \%, 30 \%$, and $40 \%$ (by weight)] to determine the impact of sweetpotato content on product functionality, nutritional content, and sensory characteristics by a small, semitrained panel. The optimum level of sweetpotato puree in the dairy-based frozen dessert from the first phase was used during the second phase to develop nondairy frozen dessert products that were evaluated by nontrained consumer participants.

'Beauregard' sweetpotatoes were secured from the Pontotoc RidgeFlatwoods Branch Experiment Station, Pontotoc, MS, and stored at room temperature and $70 \%$ relative humidity in the Food Processing Laboratory for $\approx 4$ months before being used. Milk, heavy cream, almond milk, nonfat milk solids, soymilk, coconut oil, cane sugar (extra fine, granulated), stabilizer (PGX-1; Germantown Manufacturing Co., Broomall, PA), and vanilla flavor were purchased from a local store. Sweetpotatoes were baked at $190{ }^{\circ} \mathrm{C}$ in a convection oven (HEC20; Hobart Corp., Troy, OH) for $60 \mathrm{~min}$. After baking, the skin was removed and the pulp was cooled for $30 \mathrm{~min}$. Then, the pulp was pureed at high speed in a food processor (FP-8SV; Cuisinart, Stamford, CT) for $3 \mathrm{~min}$. The puree was stored at $-18^{\circ} \mathrm{C}$ and then thawed at $4{ }^{\circ} \mathrm{C}$ in a refrigerator for $24 \mathrm{~h}$ before use. Phase one dairy-based frozen desserts contained milk, heavy cream, sugar, nonfat milk solids, stabilizer, vanilla flavor, and $20 \%, 30 \%$, or $40 \%$ sweetpotato puree (Table 1 ). The ingredient amounts were adjusted with an ice cream calculator to maintain the same percentages of fat $(10 \%)$ and sugar (16\%) in each sample. Based on findings from the dairy dessert sensory panel (see Results and Discussion), phase two nondairy frozen desserts contained 30\% sweetpotato puree and used coconut oil as a replacement for heavy cream and either almond milk or soy milk as a replacement for milk (Table 2). Nondairy desserts were compared with a milk-based control that comprised all the same ingredients except that milk replaced the soy milk and almond milk. For both phase one and phase two, all ingredients except sweetpotato puree and vanilla were mixed and heated in a pot (diameter, $30 \mathrm{~cm}$; height, $16 \mathrm{~cm}$ ) until the mixture reached $50{ }^{\circ} \mathrm{C}$. Then, the mixture was homogenized with sweetpotato puree and vanilla flavor in a food processor at the low setting for $60 \mathrm{~s}$ and cooled at $4{ }^{\circ} \mathrm{C}$ in a refrigerator for $18 \mathrm{~h}$. An ice cream machine (BCI600XL; Breville USA, Torrance, CA) was used for initial freezing for $40 \mathrm{~min}$, and the samples were stored in plastic containers for the hardening process at $-40{ }^{\circ} \mathrm{C}$ until they were analyzed.

\section{Chemical analysis}

Phase two frozen dessert samples (two replications) were thawed. Brix were measured by placing a filtered 
Table 1. Formulations of sweetpotato frozen desserts made from milk and cream with different sweetpotato contents.

\begin{tabular}{lrrrr}
\hline & \multicolumn{3}{c}{ Sweetpotato puree (\%) } & \\
\cline { 2 - 4 } Ingredient & $\mathbf{2 0}$ & $\mathbf{3 0}$ & $\mathbf{4 0}$ & \\
\cline { 2 - 4 } & \multicolumn{3}{c}{ Content $(\mathbf{g})^{\mathbf{z}}$} & Content (\% by wt) \\
\hline Milk & 375 & 269 & 160 & $16-37.5$ \\
Heavy cream & 270 & 282 & 296 & $27-29.6$ \\
Sucrose & 150 & 145 & 140 & $14-15$ \\
Sweetpotato puree & 200 & 300 & 400 & $20-40$ \\
Stabilizer & 4 & 4 & 4 & 0.4 \\
Vanilla flavor & 1 & 1 & 1 & 0.1 \\
Total & 1000 & 1000 & 1000 & 100 \\
\hline
\end{tabular}

${ }^{\mathrm{z}} 1 \mathrm{~g}=0.0353 \mathrm{oz}$.

Table 2. Formulations of sweetpotato frozen desserts made with milk, almond milk, or soy milk.

\begin{tabular}{lrcrc}
\hline & \multicolumn{3}{c}{ Frozen dessert base } & \\
\cline { 2 - 4 } Ingredient & Milk & Almond & Soy & \\
\cline { 2 - 4 } Content $(\mathrm{g})^{\mathbf{z}}$ & & Content (\% by wt) \\
\hline Milk or replacement & 466 & 455 & 463 & $45.5-46.6$ \\
Coconut oil & 84 & 95 & 92 & $0.84-0.95$ \\
Sucrose & 145 & 145 & 140 & $14-14.5$ \\
Sweetpotato puree & 300 & 300 & 300 & 30 \\
Stabilizer & 4 & 4 & 4 & 0.4 \\
Vanilla flavor & 1 & 1 & 1 & 0.1 \\
Total & 1000 & 1000 & 1000 & 100 \\
\hline
\end{tabular}

${ }^{\mathrm{z}} 1 \mathrm{~g}=0.0353 \mathrm{oz}$

(Whatman no. I filter paper; Global Life Sciences Solutions USA, Marlborough, MA) drop of each sample on the prism of a refractometer (Abbe3L; Bausch \& Lomb, Rochester, NY) and measured after calibration with distilled water. The $\mathrm{pH}$ was measured with a $\mathrm{pH}$ meter (Fisher Scientific International, Hampton, $\mathrm{NH}$ ) calibrated with buffer solutions at $\mathrm{pH} 4$ and $\mathrm{pH} 7$ before use. Total solids were measured according to the Association of Official Agricultural Chemists International (AOAC) method 925.21 (Association of Official Agricultural Chemists International, 1999). The samples were dried at $105{ }^{\circ} \mathrm{C}$ in an incubator (ISOtemp oven 200, model 215F; Fisher Scientific) for $24 \mathrm{~h}$ and the total soluble solids (TSS) were calculated as:

TSS $($ percent $)=100 \times$

final weight (grams) - dish weight (grams) initial weight (grams)

The fat content was determined according to the AOAC method 905.02 (Association of Official Agricultural Chemists International, 1999). Then, $3 \mathrm{~g}$ of frozen dessert samples were weighed and the approximate total fat content was calculated as:

$$
\begin{gathered}
\text { Fat }(\text { percent })=100 \times \\
\frac{\text { final weight }(\text { grams })-\text { dish }(\text { grams })}{\text { initial weight }(\text { grams })}
\end{gathered}
$$

The AOAC methods 990.30 and 934.01 were used to determine the protein and moisture, respectively (Association of Official Agricultural Chemists International, 1999). Fiber was measured by the American Oil Chemists' Society (AOCS) Ba6A-05 (American Oil Chemists' Society, 1998). To determine minerals, inductively coupled plasma mass spectrometry (ICP-MS) was used for metal analysis. Then, $2 \mathrm{~g}$ of frozen dessert was weighed and transferred to a microwave digestion tube with 3 $\mathrm{mL}$ of peroxide and $5 \mathrm{~mL}$ of nitric acid $\left(\mathrm{HNO}_{3}\right)$. The tube was capped and place in a carousel in a hood for 2 $\mathrm{h}$. The carousel was placed in a microwave digester (MARS Xpress; CEM Corp., Matthews, NC). The tube was cooled for $12 \mathrm{~h}$, the cap was removed, and the acid was equilibrated for 30 min in the hood. The digested samples were added to each volumetric flask with $50 \mathrm{~mL}$ of deionized water and filtered into the ICP sampler tubes with $0.45 \mu \mathrm{m}$ and $33 \mathrm{~mm}$ polyvinylidene difluoride filters. The ICPMS analyzer (7900 ICP-MS; Agilent, Santa Clara, CA) used gas plasma to determine the calcium, iron, sodium, and potassium levels.

\section{Nutrition estimation analysis}

The nutritional content of frozen desserts was estimated by a calorie calculator (Tufts University, 2019). According to the frozen dessert formula (Table 2), ingredients were searched in the USDA food composition database and calculated using the USDA software. Then, $100 \mathrm{~g}$ of frozen dessert was established as one serving.

\section{Sensory analysis}

During phase one, a descriptive sensory test of dairy-based frozen dessert formulations was conducted with a semi-trained panel $(\mathrm{n}=8)$ in a descriptive room at the Mississippi State University Garrison Sensory Laboratory, Mississippi State, MS Attributes (Table 3) were derived from those used by King (1994) and Ohmes et al. (1998); they were evaluated by the panelists using a scale of 0 (very weak) to 15 (very strong) with two replications. Interactions between panelists and treatments were analyzed by SAS (version 9.4 ; SAS Institute, Cary, NC). Data from two panelists were excluded to reduce outliers in the final statistical analysis (Lawless and Heymann, 2010).

During phase two, consumer acceptability tests involving the nondairy-based frozen desserts and a milk-based control were conducted at the Mississippi State University Garrison Sensory Laboratory $(\mathrm{n}=$ 101) and at the 2018 Annual Sweetpotato Field Day, Pontotoc RidgeFlatwoods Branch Experiment Station, Pontotoc, MS $(n=43)$. Participants at the sensory laboratory were university students or employees. Participants at the Field Day were sweetpotato growers and university or industry research/extension personnel who were generally more knowledgeable about sweetpotatoes than participants at Mississippi State University. A hedonic scale of 1 to 9 was used to rate the appearance, aroma, 
Table 3. Attributes and their definitions used by a semi-trained $(n=8)$

descriptive panel who evaluated frozen dairy desserts at the Mississippi State University Garrison Sensory Laboratory, Mississippi State, MS.

\begin{tabular}{|c|c|}
\hline Attributes & Definitions \\
\hline Appearance (color) & Intensity of orange color \\
\hline \multicolumn{2}{|l|}{ Aroma } \\
\hline Sweetpotato & Fundamental aroma strength of sweetpotato \\
\hline Vanilla & Fundamental aroma strength of vanilla \\
\hline \multicolumn{2}{|r|}{ encla } \\
\hline Sweet & Fundamental taste of sucrose $(2 \%$ sucrose $=2 ; 5 \%$ sucrose $=5)$ \\
\hline Sour & $\begin{array}{l}\text { Fundamental taste or sensation of lactic acid and citric acid } \\
(0.05 \% \text { citric acid }=2 ; 0.08 \% \text { citric acid }=5 ; 0.15 \% \text { citric acid }= \\
10)\end{array}$ \\
\hline Astringent & Measure of puckery flavor \\
\hline Milk & Intensity of dairy milk \\
\hline Sweetpotato & Intensity of sweetpotato flavor \\
\hline Vanilla & Intensity of vanilla flavor \\
\hline \multicolumn{2}{|l|}{ Texture } \\
\hline Smooth & $\begin{array}{l}\text { Possession of a custard-like body with a smooth homogenous } \\
\text { texture }\end{array}$ \\
\hline Creamy & Possession of a creamy feeling without a grainy texture \\
\hline Coarse/icy & Possession of a coarse ice texture \\
\hline Gummy & Possession of a gummy texture \\
\hline Mouth-coating & Measure of mouth-coating \\
\hline Rate of melt in mouth & Measure of melting rate in the mouth \\
\hline
\end{tabular}

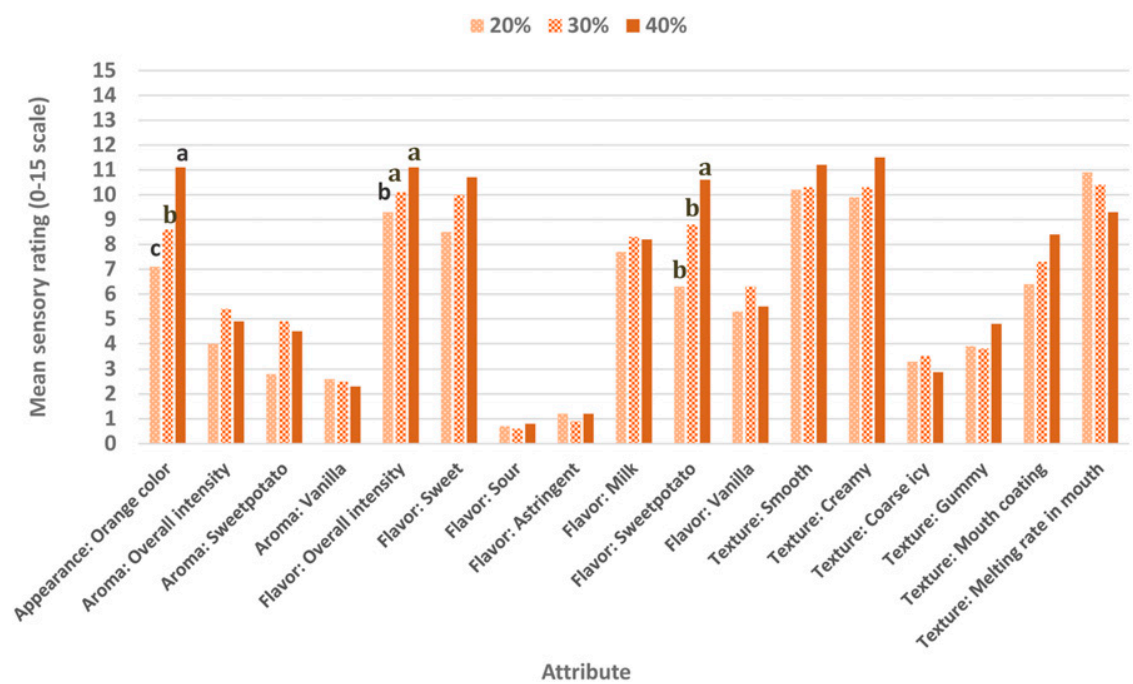

Fig. 1. Mean scores of descriptive panels for each attribute of frozen dairy desserts made with $20 \%, 30 \%$, and $40 \%$ sweetpotato puree. A $15-\mathrm{cm}$ ( 5.9 inches) line scale was used for each attribute: $\mathbf{0}=$ very weak and $\mathbf{1 5}=$ very strong. Tukey's honestly significant difference test was used to separate treatment means $(P \leq 0.05)$. Means for each attribute followed by the same letter do not differ.

flavor, texture, and overall liking of each of the frozen dessert samples.

\section{Statistical analysis}

For descriptive analysis (phase one), a randomized complete block design was used. An interaction plot was used to exclude inconsistent panelists. The remaining descriptive and chemical results were subjected to an blocks. A cluster analysis was used for the 101 panelists who participated in the consumer acceptability test at Mississippi State University; they were clustered by dissimilarities in their overall liking and preference of the samples using Ward's method of agglomerative hierarchy clustering with XLSTAT (Addinsoft, New York, NY). The number of clusters was determined by comparing the levels on a dissimilarity plot. Each cluster was analyzed by SAS, and Tukey's test was used to separate the treatment means when a difference $(P \leq 0.05)$ occurred.

\section{Results and discussion \\ Determining the optimum sweetpotato puree content in frozen dairy desserts (phase one)}

Using the aforementioned scale of 0 (very weak) to 15 (very strong), the semi-trained sensory panel determined that the intensity of the orange color increased with the increasing sweetpotato puree content; the intensity scores were 7.1, 8.6, and 11.1 for dairy-based desserts containing $20 \%, 30 \%$, and $40 \%$, respectively (Fig. 1). The amount of sweetpotato added determines the intensity of the orange color as a result of the natural beta carotene pigment (Takahata et al., 1993). All samples received low ratings for aroma attributes (4.0-5.4), coarse iciness (2.9-3.5), gumminess $(\leq 4.8)$, sourness $(0.6-$ $0.8)$, and astringency (0.9-1.2). The overall flavor intensity was stronger with $40 \%$ sweetpotato puree than with $20 \%$; the flavor intensity with $30 \%$ was similar to that with $20 \%$ and $40 \%$. However, the formulation containing $40 \%$ sweetpotato was more difficult to produce because of the difficulty incorporating both puree and air into the product. Furthermore, the authors had concerns about the stability of the $40 \%$ formulation product. Therefore, the 30\% sweetpotato puree was chosen for the frozen dessert samples used during phase two.

nalysis of variance by SAS Tukey's honestly significant difference to differentiate the treatment means when $P \leq 0.05$. For phase two, a randomized complete block design was used to evaluate differences $(P \leq 0.05)$ in the appearance, aroma, flavor, texture, and overall acceptability of sweetpotato frozen desserts. Panelists were treated as

\section{Analysis of frozen desserts (phase two)}

Chemical analysis. The $\mathrm{pH}$ of the frozen dessert samples did not differ among samples and ranged from 6.5 to 6.9 (Table 4 ). The Brix level of the almond-, milk-, and 
soy-based frozen desserts were 27.3, 31.2 , and 30.1 , respectively. The fat content of the samples averaged $10 \%$. The almond milk used in this study contained $0.4 \%$ protein, whereas the soy milk contained $2.9 \%$ and milk contained $3.8 \%$, thus resulting in the differences in TSS and Brix within desserts. The almond milk-based frozen desserts contained $90 \mathrm{mg}$ / serving of calcium, and the soy- and milk-based frozen dessert contained $68 \mathrm{mg} /$ serving of calcium (Table 5 ). The potassium contents in the soy-, almond-, and milk-based desserts were 199,148 , and $143 \mathrm{mg}$ /serving, respectively. In all samples, the iron content was not detectable and the sodium content was $\leq 35 \mathrm{mg} /$ serving. The almond milk sample contained 1 $\mathrm{g} /$ serving of crude protein, which was half that in the other samples. The crude carbohydrate contents were estimated by subtracting the crude protein and fat contents from the TSS (range, $21-23 \mathrm{~g} /$ serving).
Despite the nutritional variability among samples, adding sweetpotato puree greatly increased their nutritional value and decreased the added sugar. A $30-\mathrm{g}$ portion of sweetpotato baked in skin contains $288.3 \mu \mathrm{g}$ of vitamin A retinol activity equivalents (USDA, 2018). A 100-g serving of the frozen dessert samples containing $30 \mathrm{~g}$ of sweetpotato puree fulfills $\approx 50 \%$ of the daily recommended intake of vitamin A. The total energy values ranged from 168 to $182 \mathrm{kcal}$ (Table 5).

Consumer acceptability. Consumer acceptability data from Mississippi State and Pontotoc were evaluated separately. Panelists attending the Sweetpotato Field Day (Pontotoc) moderately liked (7.1) the frozen desserts regardless of the type of base used (Table 6). However, their knowledge of sweetpotatoes may have resulted in bias. These panelists gave higher appearance scores for milk (7.6) than for almond milk (7.1) and soy milk (7.0). The samples were given similar ratings for the

Table 4. $\mathrm{pH}$, Brix, total fat content, and total soluble solids (TSS) for frozen desserts made with $\mathbf{3 0} \%$ sweetpotato puree by weight and milk, almond milk, or soy milk.

\begin{tabular}{lcccc}
\hline Frozen dessert base & pH & Brix & Fat (\%) & TSS (\%) \\
\hline Milk & 6.5 & $31.2 \mathrm{a}^{\mathrm{z}}$ & 9.9 & $36.7 \mathrm{a}$ \\
Almond milk & 6.9 & $27.3 \mathrm{~b}$ & 10 & $33.5 \mathrm{~b}$ \\
Soy milk & 6.9 & $30.1 \mathrm{a}$ & 10 & $35.2 \mathrm{ab}$ \\
Coefficient of variation (\%) & 4.0 & 7.0 & 1.0 & 4.4 \\
SE & 0.11 & 0.85 & 0.04 & 0.64 \\
\hline${ }^{{ }^{2}}$ Tukey's honestly significant difference test was used to separate treatment means $(P \leq 0.05)$. Means within each
\end{tabular}

column followed by the same letter do not differ from one another.

Table 5. Estimated nutritional content for a 100 -g serving of frozen desserts made with $30 \%$ sweetpotato puree by weight and milk, almond milk, or soy milk based on the USDA food composition database. ${ }^{\mathrm{z}}$

\begin{tabular}{|c|c|c|c|}
\hline \multirow[b]{2}{*}{ Nutritional content $^{\mathrm{z}}$} & \multicolumn{3}{|c|}{ Frozen dessert base } \\
\hline & Milk & Almond & Soy \\
\hline Energy (kcal) & 182 & 168 & 177 \\
\hline Protein $(\mathrm{g})$ & 2 & 1 & 2 \\
\hline Total fat $(\mathrm{g})$ & 10 & 10 & 10 \\
\hline Saturated fat $(\mathrm{g})$ & 9 & 9 & 9 \\
\hline Cholesterol (g) & 7 & 0 & 0 \\
\hline Carbohydrate (g) & 23 & 21 & 22 \\
\hline Fiber $(\mathrm{g})$ & 1 & 1 & 1 \\
\hline Sugar $(\mathrm{g})$ & 19 & 16 & 17 \\
\hline Sodium (mg) & 35 & 34 & 29 \\
\hline Calcium (mg) & 68 & 90 & 68 \\
\hline Potassium (mg) & 143 & 148 & 199 \\
\hline Vitamin A (IU) & 5822 & 5853 & 5861 \\
\hline Vitamin C (mg) & 6 & 6 & 6 \\
\hline
\end{tabular}

Hortechnology · June $202131(3)$ other attributes. The panelists at the Mississippi State University Sensory Laboratory indicated that the appearance and texture of the milk-based frozen dessert $(7.6$ and 7.2 , respectively) were preferred over almondbased (6.5 and 6.4, respectively) and soy-based (6.8 and 6.5 , respectively) frozen desserts. Regarding aroma, panelists gave the milk-based frozen dessert (6.3) and soy-based frozen dessert (6.1) similar ratings, and they preferred both of those over the almond-based frozen dessert (5.7). The overall acceptability ratings were 6.9 for milk, 6.5 for soy milk, and 6.1 for almond milk.

Cluster analysis of CONSUmer ACCEPTABILITY OF FROZEN DESSERTS. Because of the lack of differences among Pontotoc panelists, a cluster analysis was conducted for the Mississippi State panelists only. Consumer panelists at the Mississippi State University Sensory Laboratory were clustered into four groups based on the overall acceptability of frozen desserts determined by a dendrogram. The mean scores based on clusters (Table 7) were as follows. Cluster 1 comprised $57.4 \%$ of the consumer panelists. These panelists did not have a preference among the three samples, with mean overall acceptability ratings of the group ranging between 7.1 and 7.4 and all three desserts rated as moderately liked. Cluster 2 comprised $22.8 \%$ of the panelists who provided similar overall acceptability ratings for milk (6.9) and soy milk (6.5). Both were slightly liked and preferred over almond milk (3.9). Cluster 3 comprised $7.9 \%$ of panelist who rated all three samples as either slightly disliked or moderately disliked (range, 3.3-4.4) without differences among the samples. Cluster 4 comprised $11.9 \%$ of the panelists who preferred milk (7.2) and almond milk (7.4) samples over soy milk (3.8).

Clusters 1, 2, and 4 rated the milk-based frozen dessert between 6.9 and 7.2 ; therefore, the treatment was rated as slightly liked or greater by the most panelists $(92.1 \%)$. The soy milk frozen dessert was scored as 6 or greater by $80.2 \%$ of panelists, and the almond milk dessert sample was scored as 6 or greater by $69.3 \%$ of panelists. Both milk and soy milk samples were slightly liked or greater by $80.2 \%$ of panelists. Milk and almond milk samples were slightly liked 
Table 6. Consumer acceptability of frozen desserts containing $30 \%$ sweetpotato by weight conducted at Mississippi State University (MSU), Mississippi State, MS $(n=101)$, and Pontotoc, MS $(n=43)$ in 2018 , and analyzed separately by location.

\begin{tabular}{|c|c|c|c|c|c|c|}
\hline \multirow[b]{3}{*}{ Characteristic } & \multicolumn{6}{|c|}{ Consumer acceptability $(1-9 \text { scale })^{\mathrm{z}}$} \\
\hline & \multicolumn{2}{|c|}{ Milk } & \multicolumn{2}{|c|}{ Almond } & \multicolumn{2}{|c|}{ Soy } \\
\hline & $\overline{\mathrm{MSU}}$ & Pontotoc & $\overline{\mathrm{MSU}}$ & Pontotoc & $\overline{\text { MSU }}$ & Pontotoc \\
\hline Appearance & $7.6 \mathrm{a}^{\mathrm{y}}$ & $7.6 \mathrm{a}$ & $6.5 \mathrm{~b}$ & $7.1 \mathrm{~b}$ & $6.8 \mathrm{~b}$ & $7.0 \mathrm{~b}$ \\
\hline Aroma & $6.3 \mathrm{a}$ & 6.5 & $5.7 \mathrm{~b}$ & 6.5 & $6.1 \mathrm{a}$ & 6.4 \\
\hline Flavor & 6.8 & 7.0 & 6.2 & 7.2 & 6.5 & 6.9 \\
\hline Texture & $7.2 \mathrm{a}$ & 7.1 & $6.4 \mathrm{~b}$ & 7.3 & $6.5 \mathrm{~b}$ & 6.9 \\
\hline Overall acceptability & $6.9 \mathrm{a}$ & 7.1 & $6.1 \mathrm{~b}$ & 7.1 & $6.5 \mathrm{ab}$ & 7.1 \\
\hline
\end{tabular}

${ }^{\mathrm{z}} 1=$ dislike extremely; 5 = neither like nor dislike; 9 = like extremely

${ }^{\text {y} T u k e y ' s ~ h o n e s t l y ~ s i g n i f i c a n t ~ d i f f e r e n c e ~ t e s t ~ w a s ~ u s e d ~ t o ~ s e p a r a t e ~ t r e a t m e n t ~ m e a n s ~}(P \leq 0.05)$. Means within each row and location followed by the same lowercase or uppercase letter do not differ from one another.

Table 7. Mean scores for overall consumer acceptability $(n=101)$ of sweetpotato-based frozen dessert samples containing $30 \%$ sweetpotato by weight according to different clusters of consumer segments at the Mississippi State University Garrison Sensory Laboratory, Mississippi State, MS, in 2018.

\begin{tabular}{lcccc}
\hline & & \multicolumn{3}{c}{$\begin{array}{c}\text { Consumer acceptability } \\
(\mathbf{1 - 9} \text { scale) }\end{array}$} \\
\cline { 3 - 5 } Cluster $(\mathbf{n})^{\mathrm{z}}$ & Panelist (\%) & Milk & Almond & Soy \\
\hline $1(58)$ & 57.4 & $7.2^{\mathrm{x}}$ & 7.1 & 7.4 \\
$2(23)$ & 22.8 & $6.9 \mathrm{a}$ & $3.9 \mathrm{~b}$ & $6.5 \mathrm{a}$ \\
$3(8)$ & 7.9 & 4.4 & 3.5 & 3.3 \\
$4(12)$ & 11.9 & $7.2 \mathrm{a}$ & $7.4 \mathrm{a}$ & $3.8 \mathrm{~b}$ \\
Panelists who rated treatment as like & & 92.1 & 69.3 & 80.2 \\
$\quad$ slightly or greater (\%) & & & &
\end{tabular}

${ }^{\mathrm{z}} 1=$ dislike extremely; $5=$ neither like nor dislike; 9 = like extremely.

'Panelists were clustered by dissimilarities of overall liking and preference of the samples using Ward's method of agglomerative hierarchy clustering. The number of clusters was determined by comparing the levels on a dissimilarity plot.

${ }^{x}$ Tukey's honestly significant difference test was used to separate treatment means $(P \leq 0.05)$. Means within each row followed by the same letter do not differ.

or more by $69.3 \%$ of panelists. Panelists who liked both the almond and soy samples comprised $57.4 \%$ of panelists.

The frozen desserts had similar fat contents but variable protein and sugar contents because of the different compositions of raw materials in the base milk/milk alternative. Results of the present study differ from those of Alozie and Udofia (2015), who reported that consumers preferred almond milk over soy milk in terms of color, flavor, taste, and overall acceptability, but that they gave similar ratings for mouthfeel for the two. However, Alozie and Udofia (2015) investigated the nutritional and sensory properties of vanilla-flavored almond milk and soy milk as beverages, not frozen desserts. In the present study, the lack of corresponding vanilla-flavored frozen desserts formulated without sweetpotato puree and using milk, almond milk, and soy milk did not permit for a potential investigation of the interactive effects of milk/milk alternative base and the presence/absence of sweetpotato puree. Furthermore, given the documented variability in consumer sensory attributes among commercial vanilla-flavored ice creams (Dooley et al., 2010), direct comparisons between the sweetpotato-based frozen desserts in this study and a vanilla ice cream standard were not possible.

During this study, it was determined that frozen desserts could contain as much as $30 \%$ sweetpotato puree. When ratings were averaged across all panelists, the sweetpotatobased frozen desserts made from milk and almond milk or soy milk had similar overall acceptability. However, the cluster analysis revealed that preferences among the three formulations differed greatly by cluster. Frozen sweetpotato desserts containing soy milk and almond milk may not be as broadly acceptable as those containing milk. Marketing efforts should be considered for those who are lactose-intolerant, allergic to milk protein, vegan, and consumers who appreciate the health benefits of sweetpotato and coconut oil.

\section{Literature cited}

Ahuja, K. and A. Rawat. 2018. Non-dairy ice cream market size by source, by flavor, by product, by form, by distribution channel industry analysis report, regional outlook, growth potential, price trend, competitive market share \& forecast, 2018-2024. Global Market Insights, Shelbyville, DE.

Alozie, Y.E. and U.S. Udofia. 2015. Nutritional and sensory properties of almond (Prunus amygdalus Var. Dulcis) seed milk. World J. Dairy Food Sci. 10:117-121, doi: 10.5829/idosi.wjdfs.2015.10.2.9622.

American Oil Chemists' Society. 1998. Official methods and recommended practices of the American Oil Chemists' Society. 3rd ed. Amer. Oil Chem. Soc., Chicago, IL.

Association of Official Agricultural Chemists International. 1999. Official methods of analysis of AOAC international. 16th ed. 5th rev. Assn. Offic. Agr. Chem. Intl., Gaithersburg, MD

Bisla, G., P. Verma, and S. Sharma. 2012. Development of ice creams from soybean milk \& watermelon seeds milk and evaluation of their acceptability and nourishing potential. Adv. Appl. Sci. Res. 3:371-376.

Bonvell-Benjamin, A.C. 2007. Sweet potato: A review of its past, present, and future role in human nutrition. Adv. Food Nutr. Res. 52:1-59, doi: 10.1016/S10434526(06)52001-7.

Burri, B.J. 2011. Evaluating sweet potato as an intervention food to prevent vitamin A deficiency. Compr. Rev. Food Sci. Food Saf. 10:118-130, doi: $10.1111 /$ j.15414337.2010.00146.x

Choo, S.Y., S.K. Leong, and F.S. Henna Lu. 2010. Physicochemical and sensory properties of ice-cream formulated with virgin $\mathrm{CO}^{-}$ conut oil. Food Sci. Technol. Intl. 16:531541, doi: 10.1177/1082013210367546.

Collart, A.J., S.L. Meyers, and J.K. Ward. 2019. Consumer perception of skinning injury in sweetpotatoes and implications for marketability: An experimental auction. HortTechnology 29:468-475, doi: 10.21273/HORTTECH04355-19.

Dooley, L., Y.S. Lee, and J.F. Meullenet. 2010. The application of check-all-thatapply (CATA) consumer profiling to preference mapping of vanilla ice cream and its comparison to classical external preference mapping. Food Qual. Prefer. 
21:394 401, doi: 10.1016/j.foodqual.2009. 10.002 .

Goff, H.D. 1997. Colloidal aspects of ice cream - A review. Intl. Dairy J. 7:363-373, doi: 10.1016/S0958-6946(97)00040-X.

Jenkins, D.J.A., T.M.S. Wolever, and A.L. Jenkins. 1988. Starchy foods and glycemic index. Diabetes Care 11:149-159, doi: 10.2337/diacare.11.2.149.

Johnson, T., N. Wilson, M.R. Worosz, D. Fields, and J.K. Bond. 2015. Commodity highlight: Sweet potatoes. U.S. Dept. Agr., Econ. Res. Serv. Pub. No.VGS-355SAl

King, B.M. 1994. Sensory profiling of vanilla ice cream: Flavour and base interactions. Lebensm. Wiss. Technol. 27:450-456, doi: 10.1006/fstl.1994.1091.

Lawless, H.T. and H. Heymann. 2010 Sensory evaluation of food: Principles and practices. 2nd ed. Springer-Verlag, Ithaca, NY.

Mäkinen, O.E., V. Wanhalinna, E. Zannini, and E.K. Arendt. 2016. Foods for special dietary needs: Non-dairy plant- based milk substitutes and fermented dairytype products. Crit. Rev. Food Sci. Nutr. 56:339-349, doi: 10.1080/10408398 2012.761950 .

Marten, B., M. Pfeuffer, and J. Schrezenmeir. 2006. Medium-chain triglycerides. Intl. Dairy J. 16:1374-1382, doi: 10.1016/j.idairyj.2006.06.015.

Meyers, S.L. 2019. State report - Mississippi. Proc. Natl. Sweetpotato Collaborators Group Annu. Mtg. 37:32.

Morgan, K.L., K. Hood, and A. Myles. 2012. Mississippi sweet potato 2012 industry evaluation. Mississippi State Univ. Ext. Serv. Publ. No. 2734.

Ohmes, R.L., R.T. Marshall, and H. Heymann. 1998. Sensory and physical properties of ice creams containing milk fat or fat replacers. J. Dairy Sci. 81:12221228

Palacios, O.M., J. Badran, M.A. Drake, M. Reisner, and H.R. Moskowitz. 2009. Consumer acceptance of cow's milk versus soy beverages: Impact of ethnicity, lactose tolerance, and sensory preference segmentation. J. Sens. Stud. 24:731-748, doi: 10.1111/j.1745-459X.2009.00236.x.

Santana, I.A., E.P. Ribeiro, and A.M. Iguti. 2011. Evaluation of green coconut
(Cocos nucifera L.) pulp for use as milk, fat and emulsifier replacer in ice cream. Procedia Food Sci. 1:1447-1453, doi: 10.1016/ j.profoo.2011.09.214.

Takahata, Y., T. Noda, and T. Nagata. 1993. HPLC determination of $\beta$-carotene content of sweet potato cultivars and its relationship with color values. Jpn. J. Breed. 43:421-427, doi: 10.1270/jsbbs1951 43.421

Tufts University. 2019. Calculating calories and nutrients in meals. 26 Oct. 2020. $<$ https://hnrca.tufts.edu/flipbook/ resources/restaurant-meal-calculator/>.

U.S. Department of Agriculture. 2018. USDA food composition database. 26 Oct. 2020. <https://ndb.nal.usda.gov/ index.html $>$.

U.S. Department of Agriculture-National Agricultural Statistics Service. 2018 QuickStats database. 26 Oct. 2020 <https://quickstats.nass.usda.gov/>

U.S. Food and Drug Administration. 2018. Requirements for specific standardized frozen desserts (2lCFRl35). <https://www.accessdata.fda.gov/ scripts/cdrh/cfdocs/cfcfr/cfrsearch.

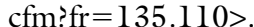

